\title{
Mat á námi og vellíðan barna: Lærdómur af samstarfsrannsókn í fimm leikskólum
}

\author{
Kristín Karlsdóttir, Margrét S. Björnsdóttir og Sara Margrét Ólafsdóttir \\ Abstract \\ - Um höfundana \\ About the authors \\ - Heimildir
}

Grein pessi fjallar um samstarfsrannsókn (e. collaborative action research) sem unnin var í samstarfi RannUng (Rannsóknarstofu í menntunarfræði ungra barna) og fimm leikskólaísveitarfélögumáhöfuðborgarsvæðinu.Markmiðpessararsamstarfsrannsóknar var að próa leiðir til að meta nám og vellíðan barna í pátttökuleikskólunum, í samræmi við áherslur í Aðalnámskrá leikskóla 2011. Tilgangurinn var að leikskólakennarar og leiðbeinendur í leikskólunum próuðu matsaðferðir sem jafnframt endurspegluðu pau viðhorf til náms sem byggt er á í leikskólastarfinu. Rannsóknin var skipulögð með samstarfsrannsóknarsniði, par sem pátttakendur í hverjum leikskóla völdu og mótuðu matsaðferðir út frá meginmarkmiðum leikskólastarfsins í samstarfi við háskólakennara og meistaranema frá Menntavísindasviði Háskóla Íslands sem studdu við ferlið og héldu utan um rannsóknir og kynningu á verkefninu. Niðurstöður leiddu í ljós að misræmi var á viðhorfum pátttakenda til náms og peirra matsaðferða sem stuðst var við í leikskólunum. Megináhersla í leikskólastarfinu var á félagsfærni, vellíðan og sköpun barna en við mat á námi hafði verið lögð áhersla á að meta proskapætti svo sem varðandi málproska og hljóðkerfisvitund. Í ljósi pess að aðstæður í leikskólunum voru misjafnar og pær leiðir sem pátttakendur völdu til að ná markmiðum í hverjum leikskóla voru ólíkar má segja að lærdómur í hverjum leikskóla beri pess merki. Í öllum leikskólunum mátti greina viðhorfsbreytingu hjá leikskólakennurum en sérstaklega hjá leiðbeinendum. Breytingin birtist í að með pví að skrá pað sem fram fór beindu leikskólakennarar og leiðbeinendur athygli sinni meira að áhuga barnanna og sjónarmið peirra urðu sýnilegri í leikskólastarfinu. Próun skráninga sem nýta mátti í mati á námi og vellíðan barna komst vel á veg í nokkrum leikskólanna. Mikilvægur páttur námssöguskráninga felst í ígrundun, en pann pátt hefou flestir pátttakendur í pessari rannsókn mátt próa betur. Tveir leikskólanna nýttu stafræna tækni meira en aðrir og pátttakendur í peim leikskólum létu vel af pví. Ekki virtist pó sem tæknin veitti meira svigrúm til ígrundunar. Skráningarnar voru gjarnan, en pó mismikið, nýttar til breytinga með pað að markmiði að styðja betur við áhuga, nám og styrkleika barna, en pær reyndust sjaldan nýttar til ígrundunar með börnunum.

Efnisord: Leikskólastarf, mat á námi og vellíðan, námssögur, pátttaka, samstarfsrannsókn

\section{Inngangur}

Um árabil hefur átt sér stað umræða um gildi leikskólamenntunar barna og í gegnum tíðina hefur ýmsum aðferðum verið beitt til pess að sýna fram á hvaða aðstæður og aðferðir eru líklegastar til að styðja við nám og proska barna. Á undanförnum árum hafa fræðimenn og leikskólakennarar tjáð ólík sjónarmið, ekki eingöngu varðandi pann aðbúnað sem börnum er boðinn, heldur einnig hvernig megi staðfesta gildi leikskólagöngunnar fyrir börn. 
Mat á leikskólastarfi og námi barna hefur fengið ólíka birtingarmynd í námskrám og starfsaðferðum sem snúa að börnum á leikskólaaldri. Í hefðbundnu námsmati í leikskólum (e. traditional assessment) er lögð áhersla á pað sem leikskólakennarar telja rétt og mikilvægt að börn læri og metið er hvað börn geta gert ein, án aðstoðar annarra. Pannig námsmat felst til dæmis í að meta börn með aðstoð staðlaðra matslista og talað er um að leggja próf fyrir börn svo sýna megi fram á nám peirra með óyggjandi hætti. Hefðbundið námsmat hefur verið gagnrýnt fyrir að pað leiði oft til pess að leikskólakennarar og foreldrar nýti pað til pess að bera saman getu barna og pað geti í kjölfarið leitt til samkeppni milli barna og leikskóla um hver stendur sig best (Brooker, 2008; Carr, 2014).

Dróaðar hafa verið matsaðferðir sem leggja meiri áherslu á aðkomu barna að mati á eigin námi, svokallaðar barnvænar matsaðferðir (e. child-friendly assessment) (Brooker, 2008). Matið felst 1 að skoða með börnunum hvað pau geta gert í samvinnu eða með stuðningi annarra. Einnig að börnin hafi meiri áhrif á hvað peim finnst mikilvægt að sé metið. Litið er á barnvænt mat sem mótandi mat (e. formative assessment), pað er að matið sé til pess gert að upplýsingar úr pví hafi áhrif á og styðji við próun náms hjá börnum. Dess konar mat getur pá til dæmis snúið að félagsfærni og líðan barna (Brooker, 2008; Carr, 2014). Barnvinsamlegar matsaðferðir eru pví í samræmi við meginhugmyndir um börn og menntun peirra á 21. öldinni.

Í Ađalnámskrá leikskóla (Mennta- og menningarmálaráđuneytið, 2012) er mikil áhersla á barnvænt mat, par sem litið er svo á að framkvæmd mats á námi barna sé órjúfanlegur páttur í starfi leikskóla, en par er almenn menntun skilgreind í ljósi nútíma samfélags, pörfum pess og einstaklingsins. Í matskafla aðalnámskrár kemur fram að mat feli í sér að safna upplýsingum um pað sem börn fást við og hafi áhuga á og að mat sé ferlimiðað. Pá er átt við að upplýsingar úr matinu séu nýttar til að styðja við nám og velferð barna, jafnt við skipulagningu leikskólastarfsins og til að styðja við og efla hvert barn. Með pessu móti er gengið út frá pví í aðalnámskrá að menntun barna fari fram í sampættu og skapandi leikskólastarfi; að hvert barn læri í gegnum leik, eigi samskipti og finni lausnir í samvinnu við jafnaldra. Í pessu samhengi er hlutverk leikskólakennara og annars starfsfólks að hvetja börn til að fást við pað sem vekur áhuga peirra og styðja við hæfni barna til að vera virk í lausnaleit í flóknu samfélagi (Mennta- og menningarmálaráðuneytið, 2012).

Í ljósi pess sem fram kemur um nám og mat í Ađalnámskrá leikskóla (Mennta- og menningarmálaráđuneytið, 2012) og framangreindra hugmynda um nám í anda samfélags 21. aldarinnar má segja að grundvallarviðhorf til barna og náms hafi breyst, sem æetti að kalla á breyttar aðferðir við mat í leikskólastarfi. Nýjar hugmyndir og skilningur á námi ungra barna hafa próast á undanförnum áratugum. Í pessari grein er vísað til samtímahugmynda sem peirra hugmynda sem próaðar hafa verið síðustu 30 árin í tengslum við menntunarfræði ungra barna (Dahlberg, Moss og Pence, 2007; Prout og James, 2015). Tengja má pessar hugmyndir við ýmsa strauma í samtímanum, til dæmis pá sem byggja á félagsfræði barnæsku (e. sociology of childhood) (Prout og James, 2015; Qvortrup, 2009), eða síðtímahugmyndum um menntun og umönnun barna (e. postmodern perspectives) (Dahlberg o.fl., 2007). Í peim er lögð áhersla á rétt barna til að hafa áhrif og að vera gerendur (e. agency) í eigin lífi (Prout og James, 2015). Í ljósi pess ætti að virða rétt barna til að fá pá umönnun sem pau parfnast en einnig rétt peirra til að á pau sé hlustað og pau studd til að hafa áhrif á sitt nánasta umhverfi. Á sama tíma (Mayall, 2003; Prout, 2011) er litið á börn sem minnihlutahóp, sem er háður fullorðnum og jafnvel sé hætta á að peir, sem hafa meira vald en pau, beiti pau kúgun eða pvingunum.

Í ljósi íslenskrar stefnumótunar, eins og kemur fram í Ađalnámskrá leikskóla og Demahefti um námsmat (Mennta- og menningarmálaráđuneytið, 2012, 2013), purfa leikskólakennarar og leiðbeinendur að huga að peim skilyrðum sem börnum eru búin pegar pau taka pátt í og tilheyra hópi í leikskólasamfélaginu, meðal annars út frá samfélagslegum aðstæðum og margbreytileika fjölskyldna á Íslandi.

Markmið pessarar samstarfsrannsóknar var að skoða og próa aðferðir sem starfsfólk leikskóla notar til pess að meta nám og vellíðan barna í samræmi við pað sem fram kemur í aðalnámskrá. 
Við val á matsaðferðum horfðu pátttakendur í rannsókninni til skráningaraðferða sem tengjast áhuga barna, styðja pau í athöfnum sínum og veita auk pess fjölskyldum peirra meiri innsýn í leikskólastarfið. Jafnframt að upplýsingar úr matinu væru nýttar í leikskólastarfinu til að styðja við nám einstakra barna, barnahópsins og við skipulag skólastarfsins.

\section{Að meta nám í ljósi nútíma hugmynda}

Námsmat sem skipulagt er í anda nútíma hugmynda um nám fer gjarnan fram pannig að fylgst er með peim ferlum sem eiga sér stað pegar börn leika sér, fást við skapandi verkefni eða annað sem vekur áhuga peirra. Skoðuð eru viðfangsefni barna og aðferðir peirra; hvað pau fást við og hvernig pau finna lausnir, oft í samvinnu við aðra. Barnvænt mat (Brooker, 2008), sem kynnt var hér að framan, felur meðal annars í sér sjónarmið barnanna sjálfra og aðkomu peirra að mati á eigin námi. Nálgunin felst í að hlusta á raddir barna, ekki aðeins orð heldur einnig að lesa í margbreytilega tjáningu peirra. Matið felst til dæmis í að finna út hvað börn vita nú pegar eða hvað pau eru að hugsa pá stundina, en ekki síður hvernig leikskólakennarar styðja börn í að kanna (e. explore) aðstæður og atburði, deila hugmyndum með öðrum og móta pannig nýja pekkingu. Leikskólakennarar sem styðjast við slíkar matsaðferðir byggja á pekkingu um nám og börn en notkun á peim styrkir jafnframt faglega próun peirra og eflir pá í að taka sjálfstæða afstöðu varðandi pað hvað peir telja mikilvægast að fari fram í leikskólanum og hvernig hægt er að meta, eða gera sýnilegt, pað nám sem par fer fram. Mat af pessu tagi snýst ekki síst um pað sem er mikilvægt fyrir barnið; vekur áhuga pess og stuðlar að samvinnu barna og samstöðu peirra á milli.

Leikskólakennarar og rannsakendur í ýmsum löndum hafa próað aðferðir til að tengja próun fagmennsku leikskólakennara og nám barna sem skipulagt er út frá áhuga og hugmyndum barna (Oliveira-Formosinho og de Sousa, 2019). Samkvæmt peim er uppeldi og menntun í daglegu starfi leikskóla síbreytilegt ferli par sem gengið er út frá pví að leikskólakennarar ígrundi og tengi saman fræði og framkvæmd í leikskólastarfinu. Dessum aðferðum er ætlað tvípætt hlutverk í mati á daglegu lífi barna í leikskólum. Annars vegar að gera pað sýnilegt og endurspegla fjölbreytta pæetti í námi og líðan barna. Hins vegar að styrkja leikskólakennara í að próa faglega og ígrundandi starfshætti. Í borginni Reggio Emilia á Norður-Ítalíu hafa uppeldisfræðilegar skráningar (e. documentation) verið próaðar, en par er lagt upp með að skrá reynslu, merkingarsköpun og hugmyndir barnsins, ígrunda skráningarnar, lesa í tjáningu barnsins og nýta ferlið sem breytingarafl í beim tilgangi að móta framsæknar aðferðir í leikskólastarfi (Dahlberg o.fl., 2007; Giudici, Rinaldi og Krechevsky, 2001). Í Nýja-Sjálandi hafa verið próaðar námssöguskráningar (e. learning stories) sem byggja á svipuðum markmiðum og aðferðum en tilgangur peirra er jafnframt að styðjast við námssögurnar sem annars konar matsaðferð sem fram fari í félagslegu samhengi (Carr, 2001, 2014). Slíkar skráningaraðferðir eru í takt við breyttar aðstæður í samfélögum 21. aldarinnar (Prout og James, 2015), par sem skólastarf byggir meðal annars á skólastefnu um skóla án aðgreiningar og fjölbreyttum menningarlegum bakgrunni fjölskyldna. Leikskólastarf í félagslegu samhengi margbreytileikans, með áherslu á rétt barna og getu til að hafa áhrif á eigið líf, kallar á nýjar aðferðir; tól og tæki sem styðja pessi markmið.

Námssöguskráning var próuð í tengslum við námskrá fyrir leikskóla, Te Whāriki (New Zealand Ministry of Education, 1996), en hún var endurskoðuð árið 2017 (New Zealand Ministry of Education, 2017). Námskráin byggir á gildum ólíkra menningarhópa par í landi par sem lögð er áhersla á að lesa í tengslamyndun í barnahópi út frá vellíðan barna (e. well-being) og að tilheyra hópi (e. belonging) sem tengist sjálfsímynd barns og hneigðar til náms (e. learning dispositions). Jafnframt er styrkleiki og geta barns í forgrunni fremur en pað sem upp á vantar í proska og færni (Carr, 2001, 2014). Hneigð til náms er skoðuð út frá eftirfarandi páttum í samskiptum barna eða barns: Sýnir barnið áhuga, er barnið virkt, hvernig leitar barnið lausna og tekst á við erfiðleika eða óöryggi, hvernig tjáir barnið hugmyndir sínar eða tilfinningar og hvernig sýnir barnið öðrum samhygð og tekur ábyrgð á pví sem fram fer? Dessir fimm pættir hneigðar til náms eru oft notaðir sem nokkurs konar viðmið, pað er að námssögurnar eru greindar út 
frá páttum hneigðar til náms (Carr, 2014; Daniels, 2011). Í íslenskri starfendarannsókn (Kristín Karlsdóttir og Anna Magnea Hreinsdóttir, 2015), sem fór fram í átta leikskólum og hafði pað markmið að próa námssöguskráningar sem matsleið, kom fram að pátttakendur yfirfærðu viðmiðin á íslenskar aðstæður með pví að tengja við pætti Ađalnámskrár leikskóla (Mennta- og menningarmálaráðuneytið, 2012). Til dæmis töldu deildarstjórar sem tóku pátt í peirri rannsókn gagnlegt að greina námssögur, gjarnan fleiri en eina, út frá peim páttum sem nefndir eru sem áherslupæettir í mati í aðalnámskránni.

Fræðimenn og leikskólakennarar í Nýja-Sjálandi telja að skráning námssagna með börnum sé góð leið til að fá innsýn í félagslegt samhengi náms í peim tilgangi að greina hvaða merkingu börn leggja í pað nám sem fram fer í leik og sköpun (Carr, 2014; Peters, 2009). Degar leikskólakennarar skrá námssögur hafa peir til hliðsjónar að í skráningunni felist fjórir meginpættir (Carr, 2001; Bryndís Garðarsdóttir og Kristín Karlsdóttir, 2012; Kristín Karlsdóttir og Anna Magnea Hreinsdóttir, 2015; New Zealand Ministry of Education, 1996, 2017):

- Fyrst fer fram skráning og lýsing, par velur leikskólakennarinn skráningaraðferð sem hentar aðstæðum og markmiði skráningar. Skráð er pað sem barnið tekst á við í samskiptum og daglegum viðfangsefnum.Val aðferðar snýst um skriflega skráningu, ljósmyndatöku, myndbandsupptöku eða hljóðupptöku. Aðferðunum er stundum blandað saman og nýlega, með tilkomu tölvutækni, hafa verið próuð forrit sem auðvelda fjölbreytta notkun aðferða og sömuleiðis utanumhald um skrár.

- Dví næst er skráningin ígrunduð og rædd við samstarfsfólk, foreldra eða börn. Ígrundun er talin nauðsynlegur páttur skráninga til að fá staðfestingu á pví sem skrád er, fá fram mörg sjónarhorn bæði barna og fullorðinna, og loks til að setja fram nýjar hugmyndir og spurningar varðandi pað sem fram fór. Ígrundunin á einnig sterkan pátt í að auka innsýn í sjónarmið barna og getur með pví móti stutt við pekkingarleit peirra, auk pess að gefa leikskólakennurunum sjálfum tækifæri til að skoða eigin starfsaðferðir.

- Dá eru gögn greind og peim miðlað í peim tilgangi að gera námsferli barna sýnilegt peim sjálfum, leikskólakennurum og foreldrum. Fram fara samræður t.d. um hvað barnið gerir, hvernig pað finnur lausnir, tjáir viðhorf sín og tekur tillit til annarra.

- Loks eru upplýsingarnar nýttar meðal annars til að endurskoða og skipuleggja leikskólastarf út frá nýjum upplýsingum um barnið eða barnahópinn (Carr, 2001; Bryndís Garðarsdóttir og Kristín Karlsdóttir, 2012; Kristín Karlsdóttir og Anna Magnea Hreinsdóttir; 2015; New Zealand Ministry of Education, 1996).

Dó pessir meginpættir séu settir fram sem nokkurs konar prep, er fremur litið á pau sem gorm par sem hægt er að fara fram og til baka í ferlinu. Framkvæmd námssöguskráninga getur til dæmis birst 1 a d skrásetjari, leikskólakennari eða leiðbeinandi, safnar saman mörgum örsögum (e. narratives), með margvíslegum aðferðum, myndum, skilaboðum, skriflegri skráningu eða upptökum. Sögurnar eru ígrundaðar; mótaðar og byggðar upp í samvinnu leikskólakennara og/ eða leiðbeinenda, barna og fjölskyldna peirra (Carr, 2014). Ígrundunin getur haft valdeflandi áhrif á alla pá aðila sem koma að henni, en ekki síst gert sjónarmið barnanna; áhuga peirra og viðhorf, peim sjálfum og öðrum sýnileg, en jafnframt stutt við áhrifamátt (e. agency) peirra (Carr og Lee, 2019). Auk pess hafa Davis, Wright, Carr og Peters (2013) rætt hvernig leikskólakennarar og leiðbeinendur geti vitað að börn ígrundi nám sitt og telja pessir höfundar að námssögur geti á árangursríkan hátt gert ígrundun peirra sýnilega, sem jafnframt getur gert námið merkingarbærara fyrir pau sjálf. Námssögum barna er hægt að safna saman í ferilmöppur (e. portfolios) og ekki er eingöngu litið á möppurnar sem námsmat sem birtist í skrásetningu á námi barna yfir tiltekið tímabil, heldur einnig að ferilmappan geti verið óendanleg uppspretta samræðu milli barna og barna og fullorðinna um pað sem barnið hefur gert og upplifað (Carr og Lee, 2019). Í peim leikskólum sem tóku pátt í pessari rannsókn var haldið utan um gögn sem varða einstök börn, lýsa ferlum í leikskólastarfi ásamt ýmsum upplýsingum um nám og líðan barna og eru pær nefndar persónumöppur (e. portfolio). 
Skráningarferlið er pannig mótandi mat (e. formative assessment); mat sem hjálpar börnum, ekki eingöngu til að skilja og styrkja eigin sjálfsmynd heldur einnig til að gera skýrar í huga hvers og eins hvernig og hvers vegna við lærum, gjarnan af pátttöku í samskiptum við aðra (Carr, 2014). Með pví móti er námssöguskráning jafnframt leið fyrir leikskólakennara og leiðbeinendur til að fá innsýn í hvernig börn leggja merkingu í auðugt en jafnframt flókið nám sem fram fer í samskiptum við aðra (Carr, 2001). Leikskólakennarar og leiðbeinendur nýta síðan upplýsingar úr matinu til að mæta barni og barnahópi, auk pess að gera breytingar á skipulagi leikskólastarfsins sem pannig er í sífelldri próun. Breytingar í leikskólastarfinu ráđast pannig af pví sem fram kemur í matinu (Peters, 2009), en fyrst og fremst er pví ætlað аð tryggja að pörfum barnanna sé mætt.

\section{Áskoranir og ávinningur sem tengjast skráningum}

Námssöguskráningar sem matsaðferð er flókið ferli en að mati Carr (2001) er ekki komist hjá pví að svo sé. Dví ber að huga að ýmsum hindrunum eða ófyrirséðum afleiðingum sem geta mætt leikskólakennurum og leiðbeinendum pegar skráð er. Nokkrar íslenskar rannsóknir lýsa upphafi námssöguskráninga í tilteknum leikskólum og pví hvernig pær hafa verið nýttar í leikskólastarfi og rannsóknum, meðal annars til að fá fram sjónarmið barna (Bryndís Garðarsdóttir og Kristín Karlsdóttir, 2012; Kristín Karlsdóttir og Bryndís Garðarsdóttir, 2008; Kristín Karlsdóttir og Bryndís Garðarsdóttir, 2010; Kristín Karlsdóttir og Anna Magnea Hreinsdóttir, 2015). Dessar rannsóknir hafa sýnt að skráningarnar reyndust árangursrík leið til að varpa ljósi á styrkleika barna. Fram kom mynd af börnum sem hæfileikaríkum pátttakendum í samskiptum við aðra, pau virtust oftast fyllilega fær um að bregðast við í vandasömum aðstæðum og taka pátt 1 að finna lausnir sem gjarnan virkuðu fyrir fleiri en pau sjálf.

Jafnt erlendar (Alvestad og Sheridan, 2015) sem innlendar (Kristín Karlsdóttir og Anna Magnea Hreinsdóttir, 2015) rannsóknir hafa sýnt að skráningar, hvort heldur sem er um námssöguskráningar eða uppeldisfræðilega skráningu að ræða, geta verið í senn hjálplegar og hvetjandi fyrir leikskólakennara, leiðbeinendur og rannsakendur, bætt við pekkingu og innsýn hinna fullorðnu í leik og námi einstakra barna og barnahópa.

Í niðurstöðum tveggja íslenskra starfendarannsókna kom fram að eftir að hafa próað námssöguskráningar sögðust leikskólakennarar finna fyrir stolti og töldu vinnubrögð sín fagmannleg. Jafnframt reyndust peim skráningarnar hjálplegar til gagnvirkrar samræðu í samstarfi við bæði samstarfsfólk sitt og foreldra (Bryndís Garðarsdóttir og Kristín Karlsdóttir, 2012; Kristín Karlsdóttir og Anna Magnea Hreinsdóttir, 2015). Sömuleiðis kom fram í sænskri rannsókn að leikskólakennarar notuðu skráningar til að bæta starf sitt og upplýsa foreldra um pað sem fram fór í leikskólanum. Auk pess varð tenging skráninga og skipulags í leikskólastarfi til pess að skilningur leikskólakennaranna á starfinu jókst og pað varð merkingarbærara í peirra augum (Alvestad og Sheridan, 2015). Út frá pessum rannsóknum má draga pá ályktun að skráningar veiti leikskólakennurum aukna innsýn í áhuga og viðhorf barna og styðji við faglega starfshætti í leikskólum.

Pó ber að halda pví til haga að pegar skráð er, hvort heldur sem er námssögur eða uppeldisfræðileg skráning, pá er mögulegt að leikskólakennarar og leiðbeinendur lendi í peim pytti að skrásetningin sjálf verði aðalatriði, á kostnað sterkra tengsla og samskipta við börnin. Í rannsókn Löfgren (2016) kom fram að leikskólakennarar sögðust sjaldan vísa til og ræða skráningar sínar sem snerust um umönnun barna, og ef peir gerðu pað bættu peir gjarnan við umræðu um nám af öðrum toga. Löfgren dró pá ályktun að leikskólakennarar litu á skráningar sem leið til að próa starfshæfni sína, en að áhersla á umönnun yrði aukaatriði eða jafnvel gleymdist. Hún taldi pessa próun geta leitt til pess að leikskólakennarar ykju áherslu á hefðbundið nám og undirbúning barna fyrir fullorðinslífið í stað pess að einblína á vellíðan barna og að börn fengju að vera börn (Löfgren, 2016). 
Helstu hindranir eða erfiðleikar sem mættu leikskólakennurum við námssöguskráningarnar (Kristín Karlsdóttir og Anna Magnea Hreinsdóttir, 2015) reyndust vera tímaskortur. Að mati pátttakenda hefði purft að gera ráð fyrir að leikskólakennarar og annað starfsfólk hefði tíma fyrir skráningar, pá sérstaklega til að ígrunda pær með öðrum. Svipað kom fram í rannsókn Alvestad og Sheridan (2015) par sem mest var stuðst við notkun ljósmynda í skráningum pátttökuleikskóla og afar sjaldgæft var að unnar væru nákvæmar skriflegar skráningar. Í peirri rannsókn leiddu niðurstöður í ljós að oft gæfist ekki tími til ígrundunar og úrvinnslu.

Halda ber pví til haga að sú nálgun að horfa til styrkleika barns og að líta á barnið sem getumikið var meðal annars sett fram í peim tilgangi að leikskólakennarar og leiðbeinendur létu ekki skráningar sínar og starfshætti stjórnast af leit að pví hvort börn stæðust tiltekin stöðluð viðmið, til dæmis byggð á próunarsálfræði, til að geta síðan unnið að pví að kenna börnum pað sem upp á vantaði samkvæmt stöðluðum proskalista. Jafnframt hefur verið sett fram sú gagnrýni (Kampmann, 2004) að hugmyndin um hið sterka og getumikla barn (e. the competent child) geti auðveldlega snúist yfir í að börn séu metin af leikskólakennurum, sem móta ný viðmið, til dæmis út frá pví hversu skapandi og kraftmikil pau séu. Kampmann bendir á að pannig verði til ný „,normalisering“ sem kalli á gagnrýna skoðun á pví hverjum pað gagnist og hvort nálgunin hafi ekki snúist upp í andhverfu sína.

Á undanförnum árum hafa skráningar tæknivæðst enn frekar. Fram kemur að í leikskólum Reykjavíkurborgar séu spjaldtölvur gjarnan nýttar til að vinna skráningar. Í spjaldtölvum eru pá snjallforrit gjarnan nýtt til að halda utan um gögn sem eru af margbreytilegum toga, svo sem ljósmyndir, myndbandsupptökur, hljóðupptökur og texta. Skrásetning í leikskólastarfinu verður með pessu móti aðgengilegri, gögnum er safnað og pau skráð á einum stað auk pess sem hægt er að útbúa rafræna ferilmöppu sem heldur utan um fjölbreytileg gögn (Skóla- og frístundasvið Reykjavíkurborgar, 2017). Jafnframt hafa rannsóknarniðurstöður sýnt að ný tölvutækni af pessu tagi geti aukið og stutt við pátttöku barna í skráningum (Alvestad og Sheridan, 2015). Í ljósi pessa má hugleiða hvort upplýsingatækni geti gagnast til að námssöguskráningar verði samofnari starfsháttum í leikskólum (Carr, 2001), par sem leikskólakennarar og leiðbeinendur pjálfi sig í að skrá og vera í samskiptum og verkefnavinnu með börnum, fremur en að standa til hliðar og vera skrásetjarar. Ekki er pó hægt að fullyrða að notkun upplýsingatækni til skráninga hafi eingöngu jákvæðar hliðar og spyrja má hvort hún gagnist eingöngu afmörkuðum hópi. Mikilvægt er að huga að pessu ef litið er á leikskólann sem lærdómssamfélag par sem allir hafa eitthvað fram að færa.

Menntun í margbreytileika aðstæðna í leikskólum er flókið fyrirbæri, bæði hvað varðar nám barna, skipulag og framkvæmd leikskólamenntunar. Ekki getur síður verið flókið að meta slíkt nám, sem kallar jafnframt á leit að fjölbreyttum matsaðferðum fremur en einni réttri leið.

Leitað var svara við eftirfarandi rannsóknarspurningum:

- Hvernig aðferðir geta nýst til að meta nám og vellíðan barna í leikskóla?

- Hvert er gildi pátttöku í samstarfsrannsókn um fjölbreyttar matsaðferðir?

\section{Аðferð}

\section{Pátttakendur}

Dátttakendur í rannsókninni voru starfsfólk í fimm leikskólum, pað er einum í hverju sveitarfélagi Kragans (Suðvesturkjördæmis), ásamt háskólakennurum og rannsakendum frá RannUng. Undirbúningur verkefnisins hófst haustið 2015 en tímarammi pess spannaði prjú ár. Meginverkpættir pátttakenda voru undirbúningur, fræðsla og innleiðing matsaðferða sem meta nám og vellíðan barna í samræmi við umfjöllun um mat í Aðalnámskrá leikskóla 2011 og Demahefti (Mennta- og menningarmálaráðuneytið, 2012, 2013). Dar sem um var að ræða samstarfsrannsókn var litið á alla pátttakendur sem sérfræðinga á sínu sviði en jafnframt rannsakendur, sem samt sem áður höfðu ólík hlutverk. 
Virkir pátttakendur í rannsókninni voru 35, pað er 25 í leikskólunum fimm, ásamt fimm meistaranemum og fimm háskólakennurum. Pátttakendur í leikskólunum voru stjórnendur í leikskólunum auk leikskólakennara og leiðbeinendur peirra leikskóladeilda sem tóku pátt í verkefninu. Fjöldi leikskólakennara sem tók pátt í hverjum leikskóla var á bilinu einn til prír, að viðbættum stjórnendum, sem allir voru leikskólakennarar. Að meðaltali var hlutfall leiðbeinenda í leikskólunum fimm um helmingur pátttakenda. Í premur leikskólanna var fastur kjarni sem tók pátt í ferli rannsóknarinnar í heild sinni. Í tveimur af leikskólunum hættu stöku pátttakendur í teyminu og komu pá nýir í staðinn. Pví má segja að aðstæður í hverjum leikskóla hafi haft áhrif á hverjir voru pátttakendur á hverjum stað og tíma. Greint verður ítarlega frá pátttakendum í öðrum greinum pessa sérrits. Hlutverk pátttakenda í leikskólunum var að skoða og greina pær matsaðferðir sem verið var að nota í upphafi verkefnisins í peim tilgangi að próa aðferðir sem eru til pess fallnar að nálgast sjónarhorn og reynslu barna, fjölbreytt nám og námsleiðir barna. Pátttakendur sóttu fundi og fyrirlestra auk pess sem peir lásu sér til og ræddu hentugar matsaðferðir miðað við aðstæður í hverjum leikskóla. Auk pess var hlutverk peirra að skipuleggja, próa og framkvæma fjölbreyttar matsaðferðir í samvinnu við fulltrúa RannUng.

Í upphafi rannsóknar var fjallað sérstaklega um siðferðileg álitamál í samræðu milli pátttakenda. Hver pátttökuleikskólanna styðst almennt við siðferðilegar reglur, meðal annars er gerður undirritaður samningur við foreldra um hvers konar gagna megi afla um börn peirra og hvernig nota megi gögnin í leikskólastarfinu. Foreldrar voru upplýstir um verkefnið og leikskólastjórar og deildarstjórar undirrituðu samning um rannsóknarsamstarf par sem peir hétu trúnaði varðandi pað sem fram kom í gögnum rannsóknar. Meistaranemar skrifuðu undir yfirlýsingu par sem peir hétu pagmælsku og virðingu í samskiptum við börn og fullorðna í leikskólunum. Til að viðhalda meðvitund um að gæta siðferðis í rannsókninni voru siðferðileg álitamál reglulega rædd á fundum meistaranema og háskólakennara í gegnum rannsóknarferlið.

Dátttakendur frá RannUng voru annars vegar háskólakennarar og rannsakendur og hins vegar meistaranemar. Hlutverk peirra fyrrnefndu var að skipuleggja og halda utan um framkvæmd verkefnisins í samstarfi við pátttakendur á vettvangi, móta rannsóknaráætlun ásamt pví að styðja meistaranema faglega og fræðilega varðandi framkvæmd innsetningar og gagnaöflun.

Hlutverk meistaranema var að halda utan um gagnaöflun (viðtöl, athuganir og fundir á vettvangi), hafa yfirsýn og halda utan um verkefnið í einum pátttökuleikskóla ásamt pví að taka pátt í kynningum. Meistaranemum bauðst að tengja meistararitgerð sína við verkefnið sem pýðir að peir gátu notað hluta af peim gögnum sem urðu til í ferlinu eða safnað eigin gögnum samhliða pátttöku í verkefninu.

\section{Aðferðafræði}

Mat á námi og vellíðan barna er svokölluð samstarfsrannsókn (e. collaborative action research). Í samstarfsrannsóknum vinna kennarar á vettvangi og utanaðkomandi rannsakendur, til dæmis háskólakennarar, náið saman. Báđir pessir aðilar geta hagnast af pátttökunni. Kennarar á vettvangi fá tækifæri til pess að breyta starfsháttum sínum, próa sig sem fagmenn og njóta stuðnings frá utanaðkomandi aðila, sem oft hefur sérfræðipekkingu á viðfangsefninu og aðferðinni. Háskólakennarar fá tækifæri til pess að tengja saman fræði og starf, tengjast fagfólki á vettvangi og vinna náið með pví. Einnig er mikil áhersla á náið samstarf kennara innan skólans par sem peir leitast við að skilja og bæta starf sitt í gegnum samvinnu (Jóhanna Einarsdóttir, 2013; Koshy, 2010). Баð er gert 1 tengslum við viðfangsefni rannsóknarinnar, sem í pessu tilfelli var að finna leiðir til pess að meta nám og vellíðan barna. Með samstarfinu er verið að skapa svokallað lærdómssamfélag.

Einkenni lærdómssamfélags (Anna Kristín Sigurðardóttir, 2013; Hord og Tobia, 2012) felst í pví grundvallarviðhorfi að litið er svo á að allir í skólasamfélaginu séu mikilvægir, hvert sem hlutverk peirra er innan og jafnvel utan skólans. Stjórnunarhættir fela í sér að starfsmannahópurinn er 
studdur til pátttöku og honum gefið færi á að koma að ákvarðanatöku. Hvatt er til samræðna par sem hópurinn deilir reynslu sinni og ígrundar hana, en með pess konar samskiptum mótast gagnvirkt lærdómsferli fyrir alla. Starfsmannahópurinn próar sameiginleg gildi um menntun barna og byggir upp sameiginlega pekkingu með hliðsjón af getu, áhuga og pörfum barnanna (Hord og Tobia, 2012). Valdefling er meginpráđur samskiptanna og hópurinn er studdur til að tjá viðhorf sín, eigin reynslu og ígrunda jafnt eigin starfsaðferðir og annarra. Valdefling í íslenskum starfendarannsóknum hefur reynst vel til pess að skapa hvetjandi námsaðstæður í skólasamfélagi í leikskóla (Kristín Karlsdóttir og Anna Magnea Hreinsdóttir, 2016; Svava Björg Mörk og Rúnar Sigpórsson, 2011). Með pví móti eru pátttakendur samstarfsrannsóknarinnar jafnframt aðilar að lærdómssamfélagi, pað er allt starfsfólk; leiðbeinendur, leikskólakennarar og leikskólastjórnendur.

Dað er engin ein rétt leið til pess að framkvæma starfendarannsókn og ferlið getur verið nokkuð ólíkt á milli rannsókna. Ferli starfendarannsókna er ekki línulegt heldur er farið fram og til baka á milli einstakra pátta yfir allt ferlið. Myndræn framsetning af hringlaga ferli getur pó auðveldað pátttakendum að átta sig á pví hvar peir eru staddir, hverju peir hafa áorkað og hver næstu skref gætu hugsanlega verið (Mac Naughton og Hughes, 2009; McNiff, 2010, 2013). Mynd 1 sýnir á einfaldan hátt ferli starfendarannsóknarinnar Mat á námi og vellídan barna.

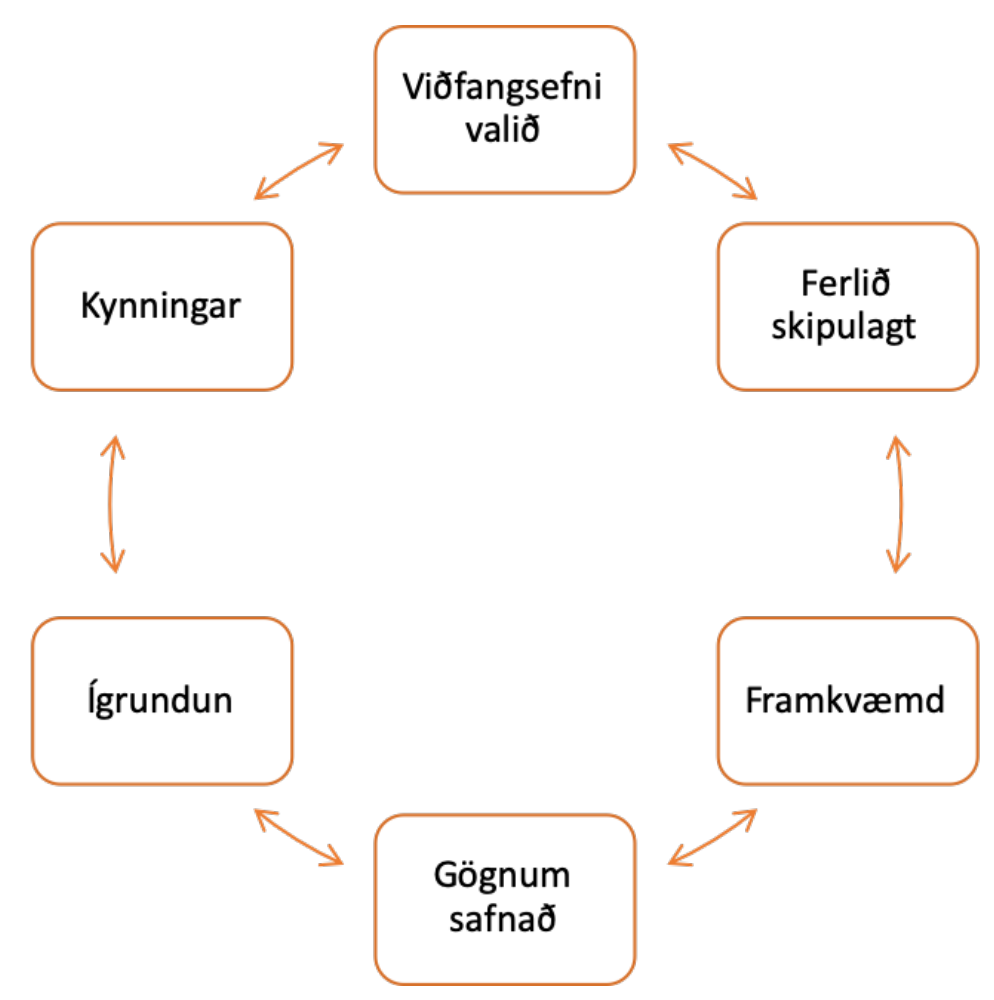

Mynd 1. Ferli rannsóknarinnar Mat á námi og vellíðan barna.

Degar pátttakendur höfðu tekið ákvörðun um að vera með í rannsókninni var komið að pví að peir veldu sér viðfangsefni. Búið var að ákveða að rannsóknin ætti að snúa að mati á námi og vellíðan. Pátttakendur í hverjum leikskóla skoðuðu pví eigið starf og greindu hvað peir vildu leggja áherslu á og bæta við í mati á námi og vellíðan barna. Á stórum fundi með öllum pátttakendum leikskólanna og háskólakennurum ígrunduðu og svöruðu pátttakendur spurningum eins og: Hvað er mikilvægt að börn læri í leikskóla? Hvað leggjum við áherslu á að meta í leikskólastarfinu núna? 
Næst var ferlið skipulagt í hverjum leikskóla. Pátttakendur studdust við spurningarnar: Hvernig ætlum við að ná okkar markmiðum? Hvernig getum við breytt okkar aðferðum við að meta nám og vellíðan barna svo að pær falli að okkar viðhorfum til mats í leikskóla? Að pví loknu var komið að sjálfri framkvæmdinni par sem pátttakendur í hverjum leikskóla prófuðu nýjar aðferðir eða leiðir sem peir töldu að myndu bæta starfið í samræmi við eigin viðhorf. Flestir völdu að vinna með námssögur og voru pátttakendur ýmist að stíga sín fyrstu skref í námssöguskráningum eða jafnvel að próa aðferðina enn frekar. Aðrar aðferðir sem pátttakendur prófuðu sig áfram með voru uppeldisfræðilegar skráningar, myndbandsskráningar og ljósmyndaskráningar.

Í gegnum allt ferlið var gögnum safnað, pað gerðu bæði pátttakendur í leikskólunum og meistaranemar frá Háskólanum. Meistaranemar tóku einstaklingsviðtöl við pátttakendur í upphafi ferlisins og aftur í lok pess. Tilgangur viðtalanna var að fá fram hugmyndir pátttakenda um mat á námi og vellíðan barna. Öðrum gögnum var einnig safnað, pau voru: Hljóðupptökur af fundum, vettvangsathuganir, ljósmyndir, myndbönd og rannsóknardagbækur. Dessi gögn voru notuð til ígrundunar og frekari greininga allra pátttakenda. Pátttakendur í leikskólunum ígrunduðu starfshætti sína stöðugt í gegnum allt ferlið; peir veltu til dæmis fyrir sér hvernig peir starfa, hvort starfshættir væru í samræmi við peirra eigin viðhorf og hvort pær breytingar sem peir prófuðu hefðu einhver áhrif. Fyrir ritun greinanna fimm greindu meistaranemar gögnin, hver í sínum leikskóla, með aðstoð háskólakennara. Gögnin voru afrituð og lesin endurtekið par til greina mátti pemu sem urðu leiðarpræðir í ritun hverrar greinar fyrir sig. Að pví loknu unnu meistaranemarnir fimm og háskólakennararnir í einum hópi að pví að draga saman, flokka og skipuleggja hin ólíku pemu sem fram komu í öllum leikskólunum.

\section{Niðurstöður}

Rannsóknin sem hér er til umfjöllunar var skipulögð sem samstarfsrannsókn, par sem pátttakendur í fimm leikskólum próuðu leiðir til að meta nám og vellíðan barna með stuðningi frá háskólateymi; einum meistaranema og einum háskólakennara í hverjum leikskóla. Í upphafi skoðuðu pátttakendur í leikskólunum fimm eigin viðhorf til barna, náms peirra og hvernig meta mætti nám. Í framhaldi af pví var tekin sú sameiginlega ákvörðun í öllum leikskólunum að skrá námssögur barna eða gera uppeldisfræðilegar skráningar, tengja við eigin skólanámskrá og nýta upplýsingarnar í að meta nám og vellíðan barna.

Meistaranemarnir greindu fyrirliggjandi gögn, hver í sínum leikskóla, með stuðningi háskólakennara, og skrifuðu grein í kjölfarið á pví (sjá aðrar greinar í pessu sérriti). Allir meistaranemarnir og háskólakennararnir unnu eftir pað í einum hópi, flokkuðu og skipulögðu pemu sem fram komu í gögnum leikskólanna. Hér í framhaldinu verða niðurstöðurnar kynntar út frá premur meginumfjöllunarefnum sem eru: Viðhorf pátttakenda í leikskólunum til náms; breytingar og áhrif pátttöku í samstarfsrannsókn og áskoranir pátttakenda í rannsóknarferlinu.

\section{Viðhorf pátttakenda í leikskólunum til náms}

Fljótlega eftir að rannsóknin hófst fór fram samræða par sem pátttakendur, sem voru 25 frá leikskólunum og fjórir háskólakennarar, ígrunduðu viðhorf sín til barna, náms peirra og mats. Í svörum allra pátttakenda í leikskólunum, varðandi hvað peim fyndist mikilvægt að börn lærðu í leikskólum, kom fram að félagsfærni, vellíðan barna og velferð peirra virtist skipta mestu máli hjá peim flestum. Einnig var tjáning, sköpun og að kenna börnum gildi oft nefnt. Í umræðunni komu einnig fram ýmis önnur hugtök pessum tengd og rætt var að pau væru í raun öll tengd og jafnvel samtvinnuð. Aðeins einn af tuttugu og fimm pátttakendum nefndi mikilvægi pess að kenna börnum að lesa. Dessi meginviðhorf eru í takt við pað sem fram hefur komið í rannsóknum Jóhönnu Einarsdóttur (2010, 2019) um væntingar foreldra til leikskólagöngu barna sinna. Foreldrarnir vildu að börn peirra nytu veru sinnar í leikskólanum, öðluðust sjálfstraust og lærðu að bera virðingu fyrir öðrum. 
Degar kom að pví að pátttakendur, sem tóku pátt í samræðunni, ræddu pær matsaðferðir sem stuðst var við í leikskólunum, nefndu pátttakendur nokkur matstæki, oftast fleira en eitt. Eins og fram kemur í töflunni hér að neðan (Tafla 1) voru eftirtalin matstæki nefnd: HLJÓM-2 sem mælir hljóðkerfisvitund; TRAS sem metur málproska; EFI sem er málproskaskimun og Íslenski proskalistinn sem er ítarlegt proskamat sem foreldrar fylla út. Einnig var nefnt ýmislegt sem tengist stefnumótun og nokkrum kennsluaðferðum eða hjálpartæki í námi og kennslu, svo sem PALS sem er aðferð til að styðja við félagalestur og SMT sem hefur pað markmið að takast á við hegðunarerfiðleika og er ætlað að móta og meta hegðun barna. Loks var ECERS-kvarðinn nefndur, en hann er notaður sem tæki til innra mats í leikskólastarfinu.

Matstæki sem skrá og halda utan um ferlimiðaðar upplýsingar voru einnig nefnd: Heilsubók barnsins par sem nákvæm skráning á proska, andlegri og líkamlegri líðan barna er gerð tvisvar á ári. Persónumöppur (e. portfolios) sem ætlað er að halda utan um verkefni sem unnin eru og endurspegla sögu barnsins í leikskólanum, skrád er út frá styrkleika pess og tengslum við önnur börn auk pess að styrkja tengsl heimilis og skóla. Námssöguskráningar par sem skráð er pað sem börn gera og geta (styrkleikar) og upplýsingar nýttar til að meta nám peirra og vellíðan.

Tafla 1. Viðhorf leikskólakennara og matsaðferðir í leikskólunum.

\begin{tabular}{|c|c|}
\hline $\begin{array}{l}\text { Pað sem leikskólakennurum fannst } \\
\text { mikilvægt að börn lærðu í leikskólum: }\end{array}$ & $\begin{array}{l}\text { Dað sem leikskólakennarar voru að nota } \\
\text { til að meta nám barna í leikskólum: }\end{array}$ \\
\hline $\begin{array}{l}\text { Flestir nefndu: } \\
\text { - Samskipti } \\
\text { - Sjálfstæði } \\
\text { - Félagsfærni } \\
\text { - Velferð og vellíðan } \\
\text { - Tjáning } \\
\text { - Sköpun } \\
\text { - Gildi }\end{array}$ & $\begin{array}{l}\text { Mjög oft nefnt: } \\
\text { - HLJÓM-2 } \\
\text { - TRAS } \\
\text { - EFI } \\
\text { - PALS } \\
\text { - Íslenski proskalistinn og aðrir tékklistar } \\
\text { Einnig kom fram: } \\
\text { - Heilsubók barnsins } \\
\text { - Persónumöppur } \\
\text { - Námssögur } \\
\text { - Námsumhverfi, kennslufræði eins og } \\
\text { ECERS-skalinn }\end{array}$ \\
\hline
\end{tabular}

Eftir pessa vinnu varð nokkur umræða á meðal pátttakenda um tengsl pess sem peir vildu eða töldu mikilvægt að leggja áherslu á í námi barna og matsaðferðunum sem notaðar voru í leikskólunum. Í umræðunni birtist ákveðin pversögn varðandi pað sem kennurum fannst mikilvægt að börn lærðu og hvaða matsaðferðum er beitt í leikskólunum (Tafla 1), pversögn sem endurspeglar ólíkar hugmyndir um nám og pað sem talið er mikilvægt að meta. Annars vegar er áhersla á leit að pví sem barnið er ekki fært um að gera, með pað að markmiði að finna leiðir til að bæta pá pætti í fari barns. Hins vegar er sú nálgun sem styðst við hugmyndir félagsfræði barnæsku par sem í mati er fókus settur á áhuga barna og styrkleika peirra í samskiptum við önnur börn og bæði nám og mat hefur pann tilgang að styðja barnið í eigin pekkingarleit sem byggir á áhuga pess og virkni.

Hugmyndir leikskólakennaranna og leiðbeinendanna um hvað var mikilvægt að meta eru í samræmi við Aðalnámskrá leikskóla sem endurspeglar samtímahugmyndir um að nám eigi sér stað í félagslegu samhengi par sem börn og leikskólakennarar ræði saman og finni lausnir í sameiningu (Carr, 2001, 2014; Mennta- og menningarmálaráđuneytið, 2012; Prout og James, 2015). Mestur hluti peirra matsaðferða sem nefndar voru byggja hins vegar á pví að skoða hvað einstaklingur getur gert einn og sér og skrá oftast án pess að eiga samskipti eða félagsleg tengsl við börn eða fullorðna. Í pátttökuleikskólunum var pví í upphafi rannsóknar aðallega stuðst við hefðbundnar matsaðferðir (Brooker, 2008). Í ljósi pessa var í hverjum leikskóla hafist handa við að leita leiða og 
móta aðferðir til að meta félagslega pætti og vellíðan barna, sem voru peir pættir sem starfffólkinu fannst mikilvægir. Í framhaldi af pessu var ákveðið að í leikskólunum yrði prófað að styðjast við námssöguskráningar eða uppeldisfræðilegar skráningar í peim tilgangi að próa annars konar matsaðferðir.

\section{Breytingar og áhrif pátttöku í samstarfsrannsókn}

Hér er greint frá peim pemum sem fram komu í niðurstöðum leikskólanna. Með pví að nota matsaðferðir sem lögðu meiri áherslu á félagsleg tengsl og vellíðan barna öðluðust pátttakendur breytta sýn á börn og nám, foreldrasamstarfið efldist og breytingar urðu á starfsháttum, pó mismiklar. Jafnframt kom fram í gögnunum að pátttakendur purftu að takast á við ýmsar áskoranir.

\section{Breytt sýn pátttakenda í leikskólunum}

Eftir að hafa stuðst við námssöguskráningar eða uppeldisfræðilegar skráningar sem matsaðferð breyttist innsýn leikskólakennara og leiðbeinenda í getu barnanna. Fram kom í niðurstöðum pátttökuleikskólanna fimm að leikskólakennarar og leiðbeinendur öðluðust breytta sýn á börn sem fólst 1 a a peir sáu betur styrkleika barna, getu peirra og færni. Um var að ræða færni sem peir höfðu jafnvel ekki veitt athygli eða sérstaklega beint sjónum að áður. Dæmi um petta birtist varðandi tvítyngd börn í einum leikskólanna - pegar starfsfólkið hætti að einblína á að börnin ættu í erfiðleikum með að tjá sig munnlega, en kom pess í stað auga á að börn áttu samskipti með ólíkum leiðum, til dæmis með líkamstjáningu og svipbrigðum. Svipað mátti greina í öðrum leikskólum í tengslum við yngstu börnin, leikskólakennarar og leiðbeinendur fóru að sjá að börnin höfðu meiri getu og samskiptafærni en peir höfðu upprunalega haldið. Pannig fannst peim námssögurnar opna huga peirra, færa peim betri innsýn í pað sem börnin tókust á við og skilning á pví námi sem fram fór. Námssöguskráningin leiddi til pess að pátttakendurnir í leikskólunum fóru almennt að sjá börnin í öðru ljósi, skilja sjónarmið peirra og greina betur hvers pau voru megnug. Petta er í samræmi við fyrri rannsóknir hér á landi og erlendis (Carr og Lee, 2012, 2019; Kristín Karlsdóttir og Anna Magnea Hreinsdóttir, 2015; Kristín Karlsdóttir og Bryndís Garðarsdóttir, 2008), par sem fram kom að námssöguskráningar gáfu leikskólakennurum betri innsýn í hugarheim barna og studdu við merkingarbær samtöl peirra við börnin.

Pátttakendur í leikskólunum upplifðu líka aukna vitund um vellíðan og nám hvers barns. Í einum leikskólanna byrjuðu leikskólakennarar og leiðbeinendur að taka eftir pví að sum barnanna hefðu fengið litla eða enga athygli frá fullorðnum í leikskólanum. Detta átti við um börnin sem sumir pátttakenda vísuðu til sem „týndu börnin“ í leikskólanum, pað er pau börn sem eru róleg og kalla ekki á mikla athygli. Pátttakendur í leikskólanum veltu fyrir sér hvort sum pessara barna gætu fundið til óöryggis sem pau tjáðu með pessum hætti meðan hjá öðrum börnum væri petta peirra tjáningarmáti. Leikskólakennarar og annað starfsfólk velti fyrir sér hvort sum pessara barna gætu verið sérlega fær í að bjarga sér og fara eftir reglum án pess að leita eftir athygli og stuðningi frá leikskólakennurum og leiðbeinendum. Detta leiddi til pess að pátttakendur í leikskólanum leituðu eftir pví að lesa betur í tjáningu pess hluta barnanna sem höfðu sig lítið í frammi og greina hvernig peim liði í leikskólanum. Tengja má petta við niðurstöður nýlegrar íslenskrar rannsóknar (Sara Margrét Ólafsdóttir og Bryndís Garðarsdóttir, 2016) par sem kom fram að tengsl væru milli aukinnar vellíðanar barna og virkrar pátttöku peirra í barnahópnum.

\section{Efling samstarfs við foreldra}

Niðurstöðurnar sýna einnig að í sumum leikskólanna próaðist og efldist samstarf við foreldra. Í tveimur af peim fimm leikskólum sem tóku pátt deildu leikskólakennararnir skráningunum með foreldrum sem leiddi til gagnvirkari samskipta við pá. Foreldrasamtöl urðu til dæmis ánægjulegri og beindust meira að jákvæðum eiginleikum barnanna, styrkleikum peirra og hversu fær pau 
væru í raun og veru fremur en pví sem börnin höfðu ekki náð valdi á. Pannig byggðu foreldrar og leikskólakennarar, með aðstoð námssagnanna, upp sameiginlega pekkingu á pví hvað barnið fengist við, áhugasviði pess og getu. Með pessum hætti fengu foreldrar aukin tækifæri til að fá innsýn í hvað barnið peirra gerði í leikskólanum - til dæmis hvernig pað notaði reynslu sína í leiknum og notaði leik og samskipti við vini sína sem vettvang til að æfa og efla félags- og samskiptafærni sína.

Í einum leikskólanna fóru börnin jafnframt heim með möppu með námssögum sínum yfir helgi og sumir foreldrar skrifuðu námssögur sem barnið kynnti svo í leikskólanum. Einum pátttakanda fannst pessi hluti rannsóknarinnar vera sá skemmtilegasti, sagði að pað hefði verið áhugavert að lesa námssögurnar að heiman og heyra börnin deila peim með barnahópnum. Svipaðar niðurstöður hafa komið fram í fyrri rannsóknum (Bryndís Garðarsdóttir og Kristín Karlsdóttir, 2012; Kristín Karlsdóttir og Bryndís Garðarsdóttir, 2008) par sem leikskólakennarar sögðu að skráningar námssagna hefðu m.a. nýst á pann hátt að foreldrasamtöl hefðu orðið ánægjulegri fyrir báða aðila, snúist meira um barnið (samskipti pess, getu og nám) og aukið í framhaldinu gagnvirk samskipti beggja aðila um barnið.

\section{Breyttir starfshættir í kjölfar námssöguskráninga}

Eins og áđur hefur verið nefnt sýndu pátttakendur opnara hugarfar gagnvart börnunum og fóru að lesa í tjáningu barnanna í ríkara mæli. Peir greindu meiri smáatriði í samskiptum og sáu pannig pað sem börnin gerðu og tjáðu út frá öðru sjónarhorni. Með pessu móti greindu peir aðra pætti í hegðun og tjáningu barna, eins og hvernig vellíðan og hæfni/færni peirra endurspeglaðist í samskiptum. Petta má tengja við einn megintilgang námssöguskráninga sem hefur jafnframt komið fram í fyrri rannsóknum að skráningar séu vel til pess fallnar að gefa leikskólakennurum og öðru starfsfólki betri innsýn í hugmyndir og áhuga barna pegar pau taka pátt í leik og öðrum viðfangsefnum (Carr, 2001, 2014; Kristín Karlsdóttir og Anna Magnea Hreinsdóttir, 2015; Kristín Karlsdóttir og Bryndís Garðarsdóttir, 2008).

Degar pátttakendur einblíndu á styrkleika barnanna og fylgdu athöfnum og samvinnu peirra eftir, sáu peir börnin í nýju ljósi, og á sama tíma reyndu peir að sjá börnin meira heildrænt. Til dæmis í einum leikskólanna, eftir að margar námssögur höfðu verið skráðar, komust pátttakendur að pví að engar sögur höfðu verið skráðar um sum börn. Pá var ákveðið að veita pessum tilteknu börnum sérstaka athygli, sem varð einnig til pess að vellíðan pessara barna og annarra á deildinni varð í brennidepli. Í öðrum leikskóla voru skráningar gerðar með börnum af erlendum uppruna, sem voru ekki farin að ná góðum tökum á íslensku. Par komust pátttakendur að pví að með pví að lesa í annars konar tjáningu barnsins heldur en tungumálið, fengu peir miklu meiri upplýsingar og skilning á henni. Detta má tengja við að einn meginpáttur í framkvæmd skráninga felst í að lesa í fjölbreytta tjáningu barna, aðra en orð, svo sem hljóð og líkamlega tjáningu í peim tilgangi að fá innsýn í hugmyndir peirra (Carr, 2014). Auk pess hafa námssöguskráningar verið teknar upp í ýmsum löndum (Carr og Lee, 2019), meðal annars við aðstæður par sem markmiðið hefur verið að styðja við félagslegt réttlæti pegar unnið er með börnum sem tilheyra fjölskyldum í minnihlutahópum viðkomandi samfélags.

Geta ber pess að pátttaka í rannsókninni reyndist sérstaklega lærdómsrík fyrir leiðbeinendurna, peir styrktust og fengu dýpri skilning á samskiptum og pví námi sem fram fer í leik barna. Leiðbeinendurnir lýstu reynslu sinni eins og um væri að ræða peirra eigið nám til að skilja börnin betur, vita meira um pau og peirra hugmyndir. Segja má að petta staðfesti að skráningar geti meðal annars verið tæki fyrir starfsfólk til að læra um börn, en einmitt pað er eitt meginmarkmið skráninga (Alvestad og Sheridan, 2015; Carr, 2014; Kristín Karlsdóttir og Anna Magnea Hreinsdóttir, 2015; Rinaldi, 2005).

Bæta má hér við að einn leiðbeinandi sagði meistaranema frá pví að jafnvel pó að hún hefði ekki skráð neinar námssögur sjálf pá hefði hún lært mikið af pví að taka pátt í ígrundun á námssögum 
samstarfsfólksins. Detta styður við rök um mikilvægi ígrundunar, en reynslu leiðbeinandans má einnig tengja við hugmyndir um valdeflingu í lærdómssamfélagi leikskóla, par sem eingöngu pátttaka í ígrundun varð til pess að hún upplifði sig sem pátttakanda í rannsókninni (Svava Björg Mörk og Rúnar Sigpórsson, 2011).

Degar pátttakendur voru farnir að sjá börnin í nýju ljósi, fóru peir einnig að fylgjast með og skrá aðrar upplýsingar og pví fylgdi að mat á námi barna varð meira í takt við aðalnámskrá. Par sem $2 / 3$ starfsfólks leikskóla eru leiðbeinendur (pað er að segja ekki menntaðir leikskólakennarar) pá er pað dýrmætur kostur að peir taki pátt í rannsókn sem pessari, en eitt af meginmarkmiðum starfendarannsókna er að valdefla leikskólakennara og annað starfsfólk (leiðbeinendur) í leikskólunum (Koshy, 2010).

\section{Dátttaka í samstarfsrannsókn - áhrif félagslegra aðstæðna}

Í premur leikskólanna var mat á námi og vellíðan barna bætt eða pví breytt og jafnvel er hægt að tala um að varanleg breyting hafi orðið á hugarfari og starfsháttum leikskólakennara og leiðbeinenda. Í tveimur leikskólanna náđi pátttaka í rannsókninni engu að síður ekki að hafa tilætluð áhrif hvað varðaði próun fjölbreyttari matsaðferða. Đó ber að halda pví til haga að fram kom í gögnum frá pessum tveimur leikskólum að viðhorfsbreyting hefði átt sér stað meðal pátttakenda og jafnvel að einhverju marki verið teknir upp breyttir starfshættir hvað varðar mat.

Auk breytinga á starfsháttum mátti í sumum leikskólanna sjá breytingar á reglum eða skipulagi deildar. Eftir að hafa gert skráningar með pví að beina sjónum að styrkleikum barnanna ásamt pví að ígrunda skráningar sáu pátttakendur börnin á annan hátt. Dað kom til dæmis fram í skráningu drengs sem var oft órólegur og virtist jafnvel áhugalaus um viðfangsefni innan dyra. Dessi drengur virtist bæði virkur og áhugasamur pegar hann var í útivist. Eftir ígrundun á pátttöku hans og tjáningu í skráningunum komust leikskólakennarar og leiðbeinendur að pví að hann gæeti haft meiri áhuga á pví að leika sér utandyra og eftir pað bauðst honum að fara út tvisvar á dag í stað einu sinni, ef hann vildi pað. Detta virðist ekki mikil breyting en engu að síður ný nálgun sem tók mið af pví að mæta áhuga barnsins, fremur en að fylgja skipulagi. Í öðrum leikskóla deildu pátttakendur námssögunum með tveggja ára börnum með pví að hengja námssöguskráningarnar upp á vegg, í hæð barnanna. Við pessar aðstæður tjáðu börnin mikinn áhuga á skráningunum, sýndu öðrum börnum og ræddu námssögurnar, en pessi háttur var hafður á og varð að venju á viðkomandi deild. Hér má tengja við rannsókn Alvestad og Sheridan (2015) sem sýndi að tengsl skráninga og skipulags í leikskólastarfi jók skilning leikskólakennara á starfinu og pað varð peim merkingarbærara.

Í öllum fimm leikskólunum próuðu pátttakendur tölvufærni sína, en pó var sú notkun hvað mest í tveimur leikskólanna, par sem notaðar voru spjaldtölvur með forritum sem héldu utan um skráningar. Drátt fyrir að tölvufærni ykist í öllum leikskólunum pá mátti greina í gögnunum að pað skilaði sér ekki alltafí dýpri ígrundun á samskiptum, námi og vellíðan barnanna. Mögulega skýrist petta af pví að í upphafi hafi notkun á nýrri tækni krafist mikillar einbeitingar pátttakendanna og pví ekki fundist rými fyrir ígrundun, að minnsta kosti meðan á gagnaöflun stóð. Detta bendir til pess að huga purfi sérstaklega að tækninotkun við skráningar í leikskólastarfi, en ljóst er að notkun spjaldtölva við skráningar hér á landi er orðin algeng (Skóla- og frístundasvið Reykjavíkurborgar, 2017). Jafnframt má halda pví til haga að í rannsókn Alvestad og Sheridan (2015) kom fram að notkun tölvutækni í skráningum gæti aukið og stutt við pátttöku barna í peim.

Í pessari rannsókn var eingöngu í einum leikskólanna minnst á að námssögurnar hefðu verið sýndar börnunum og sá mikilvægi páttur að sjónarmiðum barna væri komið á framfæri var varla orðaður og lítt sýnilegur í pátttökuleikskólunum. Í Nýja-Sjálandi par sem námssögurnar voru próaðar er mikil áhersla lögð á að ígrunda námssögur með börnum (Carr, 2011). Í fyrri rannsóknum um skráningu námssagna á Íslandi kom fram að oftar hefði mátt gefa sér betri tíma fyrir ígrundun og einnig að ígrundun með börnum hefði ekki orðið að viðtekinni venju. Dví er áhugavert 
viðfangsefni að ræða hvers vegna pað virðist vera nokkuð stórt skref fyrir leikskólakennara og leiðbeinendur í pessum rannsóknum að deila og ígrunda námssögur með börnum, sérstaklega í ljósi tilmæla par um í Aðalnámskrá leikskóla (Mennta- og menningarmálaráđuneytið, 2012) og Demahefti um námsmat í leikskólum (Mennta- og menningarmálaráðuneytið, 2013).

\section{Áskoranir pátttakenda við námssöguskráningar}

Áskoranirnar við að skrá námssögur sem pátttakendur í pessari rannsókn purftu að kljást við fólust meðal annars í pví hversu langan tíma pátttakendur purftu í upphafi til að leita að og velja markmið með skráningunum og hvaða skráningaraðferðir væru vænlegar til notkunar. Einnig voru í mörgum tilfellum gerðar skráningar án pess að eiginleg ígrundun færi fram um pað sem skráð var. Í einum leikskólanna var pó allt sem hafði verið skráð, hjá hverju barni og í barnahópi, yfir veturinn tekið saman, ígrundað og útbúin skrifleg samantekt í lok skólaársins, í peim tilgangi að upplýsingar fylgdu barni við flutning á næstu deild og einnig heim til fjölskyldna peirra.

Í pátttökuleikskólunum fólst auk pess áskorun í að skipuleggja og finna tíma til að byrja skráningarnar og ekki síður að ná að ígrunda pær. Flestir pátttakendanna gáfu sér ekki nægilegan tíma til að prófa sig áfram, gera mistök og finna lausnir sem hentuðu starfinu í viðkomandi leikskóla, en auk pess náđist allt of sjaldan að ígrunda skráningarnar. Dess í stað fór í sumum leikskólanna nokkur tími í að leita skjótra og auðveldra lausna til pess að skrá námssögurnar og virtist áherslan oft vera á fjölda skráninga fyrir hvert barn frekar en á að skráningarnar veittu upplýsingar sem nýta mætti til próunar skólastarfsins eða til að mæta barnahópnum og einstökum börnum. Fyrri rannsóknir (Bryndís Garðarsdóttir og Kristín Karlsdóttir, 2012; Carr, 2011; Dahlberg o.fl., 2007) hafa sýnt að ígrundun skráninganna er aðalatriði, par sem með ígrundun öđlast leikskólakennarar dýpri skilning á pví sem fram fer, bæði út frá börnunum og skilningi á eigin starfsaðferðum. Auk pess kom fram í rannsókn Alvestad og Sheridan (2015) að eitt meginmarkmið pátttakenda í peirri rannsókn var að nýta upplýsingarnar úr skráningum til að hafa áhrif á skipulag og framkvæmd leikskólastarfsins (Alvestad og Sheridan, 2015).

Í niðurstöðum peirrar rannsóknar sem hér er kynnt fólst jafnframt nokkur áskorun í að sumir pátttakendanna sáu ekki gildi pess að skrá námssögur. Deir upplifðu námssögurnar sem viðbót við nú pegar annasama daga. Petta viðhorf er skiljanlegt í ljósi pess að í leikskólunum var engu öđru sleppt úr leikskólastarfinu í stað pátttöku í rannsókninni, og í sumum peirra var ekki heldur áætlaður tími í skipulagi fyrir námssöguskráningarnar. Eins og fram hefur komið í fyrri rannsóknum pá parf í skipulagi leikskólastarfsins að gera ráð fyrir tíma til að ígrunda og ræða saman í hóp um skráningar og mat (Kristín Karlsdóttir og Anna Magnea Hreinsdóttir, 2015).

\section{Lærdómur af pátttöku leikskóla í samstarfsrannsókn}

Pátttakendur rannsóknarinnar störfuðu í fimm leikskólum og líta má á hvern peirra sem sérstakt samfélag með eigin starfsemi og menningu. Verkefnið próaðist með ólíkum hætti innan peirra og hafði misjafnlega mikil áhrif.

Við upphaf rannsóknarinnar höfðu liðið fimm ár frá pví að nýjasta Aðalnámskrá leikskóla kom út en pað var árið 2011. Dar var sett fram áhersla á grunnpætti menntunar (námssviðin) sem mikið hefur verið unnið með í leikskólum. Einnig er til staðar í aðalnámskránni áhersla á mat á námi og vellíðan barna, sem var ný við útgáfu hennar. Svo virðist sem að próun nýrra matsaðferða hafi verið komin styttra á veg í pátttökuleikskólunum, en próun annarra pátta í núgildandi aðalnámskrá. Mögulega gæti pað skýrt hversu misvel pátttakendum tókst að tileinka sér pað markmið verkefnisins að próa annars konar matsaðferðir og útskýrt að hluta til hvers vegna pað var frekar seint í gang.

Eins og fram kemur í gögnum rannsóknarinnar var tímarammi pessarar starfendarannsóknar of pröngur, að minnsta kosti framkvæmdahlutinn sjálfur, en hann náði yfir eitt skólaár. Jafnframt 
má segja hið augljósa að „,góðir hlutir gerast hægt“. Engu að síður vakna spurningar um hvort aðstæður í íslenskum leikskólum séu sérlega erfiðar nú um stundir og að pað kalli meðal annars á að leikskólakennarar og leiðbeinendur leiti aðallega að matsaðferðum sem eru „auðveldar og öruggar" eins og einn pátttakenda tjáði sig um í viðtali.

Í pátttökuleikskólunum urðu námssöguskráningarnar viðbót við pað mat sem fyrir var, sem skýrir að hluta hvers vegna erfitt reyndist að finna tíma fyrir námssöguskráningar. Andstæður hugmyndagrunnur peirra matsaðferða sem fyrir voru í leikskólunum og námssöguskráninga getur að hluta til hafa haft áhrif á hvernig tókst að innleiða námssöguskráningar, sérlega í peim tveimur leikskólum par sem áhrifin voru minnst. Jafnframt má ætla að pær andstæður sem fram komu milli pess sem allir pátttakendur leikskólanna töldu mikilvægt að börn lærðu og peirra matsaðferða sem í upphafi var stuðst við í pátttökuleikskólunum hafi mögulega seinkað próun nýrra starfshátta hvað varðar mat. Pær matsaðferðir sem stuðst var við í leikskólunum við upphaf rannsóknar og haldið var áfram að nota, meðan á rannsókninni stóð, tengjast hefðbundnu námsmati (Brooker, 2008), par sem lögð er áhersla á að meta hvort börn geti sýnt fram á að pau hafi tileinkað sér ákveðna pekkingu eða náð tilteknum proska. Námssöguskráningar sem matsaðferð teljast vera barnvænt mat (Brooker, 2008), fela í sér að skrá hvað börn eru fær um að gera í samvinnu við aðra og að börn séu pátttakendur í mati sem með pví móti felur í sér sjónarmið barnanna sjálfra. Velta má fyrir sér hvort pessar andstæður séu einfaldlega ekki of miklar svo unnt sé að skipuleggja samhliða mat sem byggir á pessum andstæðu hugmyndum.

Halda ber pví til haga að pað að skrá námssögur er ekki einfalt og auðvelt. Dvert á móti má vísa til ummæla Carr (2001) sem sagði að til að meta flókið og fjölbreytt nám sem fram fer í félagslegu samhengi dygðu engar einfaldar aðferðir. Niðurstöður pessarar rannsóknar sýna að mat á námi í pátttökuskólunum byggði í upphafi á matsaðferðum sem flestar gengu út á leit að pví sem börn voru ekki fær um að gera, í peim tilgangi að geta kennt peim pá pætti. Námssöguskráningum er hins vegar ætlað að byggja á styrkleikum barna og styðja pau pannig í að próa pekkingu sem vekur áhuga peirra.

Niðurstöður pessarar rannsóknar sýna að í sumum tilvikum urðu foreldrar pátttakendur í skráningum par sem peir fengu upplýsingar úr matinu, til dæmis í ferilmöppum og var boðið upp á samræður og jafnvel ígrundun á námssögum barna sinna. Jafnframt kom fram að einhverjir foreldrar skráðu námssögur heima. Dátttaka barnanna var hins vegar afar lítil í pessum fimm leikskólum, að frátöldum einum leikskóla par sem skráningar barnanna voru peim aðgengilegar. Augljóslega parf að huga betur að pátttöku barna í mati á eigin námi í pessum leikskólum.

\section{Lokaorð}

Á lokastigum rannsóknarinnar var lögð áhersla á að meistaranemar og háskólakennarar kynntu niðurstöður hennar og kæmu á framfæri nýrri pekkingu í leikskólasamfélagið svo fleira fagfólk gæti notið góðs af reynslunni. Kynningar voru meðal annars í formi erinda á ráðstefnum. Hópurinn hélt kynningu í sameiginlegri málstofu á ráđstefnu EECERA-samtakanna í Búdapest 1 ágúst 2018 og á Menntakviku í október 2018. Að auki rituðu meistaranemar og háskólakennarar greinar til birtingar í pessu sérriti Netlu.

Dó pessi rannsókn hafi einkum snúið að starfi leikskólakennara og leiðbeinenda í leikskólum er aldrei of oft ítrekað að börn og foreldrar eiga að vera pátttakendur í mati í leikskólastarfi. Eitt af markmiðum skráninga er að fá fram sjónarmið allra aðila í lífi barna og einn páttur pess er að foreldrar eigi aðild að pví lærdómssamfélagi sem leikskólum er ætlað að vera. Auk pess hafa sjónarmið peirra sem koma að ytri stjórnun leikskóla, til dæmis af hálfu sveitarfélaga og íslenskir stefnumótunaraðilar, vægi pegar kemur að mati á leikskólastarfi.

Ítreka ber að annars konar námsmat, svo sem námssöguskráning, virðist lítið próuð í flestum pátttökuleikskólanna. Námssöguskráningar parf að skipuleggja út frá pví hvenær og hvernig ber að vinna að peim. Eins og kom fram í rannsókninni má benda á nokkur mikilvæg atriði. 
Dað sem parf að huga að við námssöguskráningar:

- Æskilegt er að skráningar í leikskólum séu samofnar öllu starfi leikskólans

- Styrkleikar barna og vellíðan ættu að vera í forgrunni pegar skráð er

- Ígrundun allra aðila er lykilatriði, pað er leikskólakennara, leiðbeinenda, barna og foreldra

- Gera parf ráð fyrir tíma fyrir ígrundun og úrvinnslu námssagna

Með pátttöku bæði leikskólakennara og leiðbeinenda getur námssöguskráning reynst valdeflandi fyrir báða aðila en ekki síst fyrir leiðbeinendur. Með pví móti próast leikskólastarfið enn frekar í pá átt að vera lærdómssamfélag en í pessari rannsókn kom fram gildi pess að skipuleggja samstarfsrannsókn í peim tilgangi að vinna að breytingum í leikskólastarfi.

Sérstaða í íslenskum leikskólum felst í samsetningu starfsmannahópsins, par sem eingöngu um einn priðji hluti starfsfólks er leikskólakennarar. Tveir priðju hlutar starfsfólksins eru leiðbeinendur sem hafa afar misjafnan bakgrunn, en búa að öllu jöfnu ekki yfir sérpekkingu á sviði menntunarfræði ungra barna. Ekki er petta hlutfall aðeins í misræmi við lög, par sem kveðið er á um að tveir priðju hlutar starfsfólks leikskóla eigi að vera leikskólakennarar, heldur getur reynst flókið að veita leiðbeinendum handleiðslu til að geta starfað samkvæmt stefnumótun um leikskólastarf. Lögum samkvæmt ber leikskólum að meta nám og vellíðan barna og er pessi rannsókn liður í peirri vegferð að próa matsaðferðir í anda aðalnámskrár leikskóla.

Að lokum má geta pess að meistaranemarnir töldu sig hafa dýpkað pekkingu sína á námi og vellíðan barna, pá sérstaklega varðandi námssöguskráningar. Peir lærðu að halda utan um starfendarannsókn og stýra henni áfram með pví að styðja við pátttakendur. Deir sögðust hafa lært mikið af pátttökunni, meðal annars hefði hún eflt pá sem rannsakendur. Deir fundu líka í gegnum ferlið hversu mikilvæg ígrundunin var og sérstaklega hversu gefandi var fyrir pá sú sameiginlega úrvinnsla (meistaranema og háskólakennara) sem peir tóku pátt í, ásamt kennurum sínum. Einn meistaranemanna komst svo að orði: „Við lærðum að lítil skref geta engu að síður verið skref í rétta átt.“

\section{Assessing learning and well-being. Collaborative action research in five preschools}

The article reports on collaborative action research conducted jointly between RannUng (Centre for Research in Early Childhood Education) and five preschools in municipalities in the Reykjavík area. The aim of this action research was to develop methods to assess children's learning and well-being as stated in the National curriculum guide (Mennta- og menningarmálaráðuneytið, 2012) [Ministry of Education, Science and Culture 2011 (2012)]. According to the National curriculum, varied assessment methods should be used in relation to the curricular aims. Children should be participants in the assessment and supported in reflecting on their own learning. Also, preschool teachers are expected to share and reflect on assessment together with parents. Therefore, a collaborative action research project was planned, for the purpose of assisting preschool teachers and assistant teachers in creating methods to capture children's interest and activities in order to develop assessment practices that would reveal children's learning and well-being in their play and interaction. Another aim was to share with families insights into children's lives in the preschools and to use this information to improve preschool practice.

During the first steps of the research project, preschool teachers and assistant teachers explored their own perspectives of children and their learning and mapped existing preschool assessment methods. As the participants regarded social skills and children's well-being as the most important factors in preschools, they came to the conclusion 
that documentation might help to provide insight into children's ways of interacting; their ideas, creative powers and well-being. Consequently, the participants acquainted themselves with documentations, starting by practicing documenting Learning Stories developed in New Zealand as an assessment method. According to the action research design the participants in each preschool chose and developed ways of documenting, focusing on how to make documentations and use the information for assessment in relation to the school curriculum in each of the five preschools. Master students' role in this collaboration was to support the process in the preschools, conduct interviews and make observations, guided by the university teachers through the entire process. The students also consulted the preschool teachers and assistant teachers as they took part in writing about the study and presenting its findings.

The analysis built on data from interviews with participants in the preschools, research diaries and observations from all participants. The results showed that in the beginning there was a discrepancy between what the participants in the preschools saw as important to address in preschool education and the assessment methods used in the preschools. The social situation in each of the five preschools was different and thus the process of the project reflected different learning paths.

Through the process of the research, in all five preschools, a change of attitudes was detected among the participants, not least amongst the assistant teachers. For them, taking part in this process seemed to be educational, they became stronger in their role as assistant teachers and acquired a deeper understanding of children's interactions when playing and taking part in other activities. The preschool teachers and assistant teachers started to focus their attention towards what was of interest to the children and children's views became more visible in the preschools. In some of the preschools the use of documentations became part of assessing children's learning and well-being. However, reflection as an important part of documentation was lacking or weak in some of the preschools. The participants in two preschools used more digital technology than the others, and even though there were some challenges in the beginning they praised these tools as easy to use and suitable for organizing all the different forms of data from the documentations. It has to be acknowledged that in these two preschools the space for reflection was rather scarce at the time of the study. In two of the preschools information from the learning stories had only been used to a small extent to change the preschool plan. In the other three preschools, not only had new assessment practices been adopted, but also rules within the classrooms and the preschools as a whole were changed.

What we have first and foremost learned from this collaborative action research project is that many challenges arise in relation to both collaborative action research and developing methods to assess children's learning and well-being. It needs to be taken into account that not only have both parents and children the right to take part in assessment in preschools, they can also be important participants in the Learning Story process. Furthermore, it needs to be underlined that in Learning Stories and other types of documentation it is recommended that documenting should be integrated into all parts of preschool practice.

Key words: Preschool, assessing learning and well-being, Learning Stories, participation and collaborative action research 


\section{Um höfundana}

Kristín Karlsdóttir (krika@hi.is) er dósent í menntunarfræði ungra barna við Menntavísindasvið Háskóla Íslands. Kennsla hennar og rannsóknir snúa að ígrundun og fagpróun leikskólakennara, pátttöku barna í leik og námi, börnum sem áhrifavöldum í eigin lífi og lýðræðislegu leikskólastarfi. Auk pess hefur hún fjallað um námssöguskráningar og mat í leikskólastarfi. Hún er forstöðukona RannUng og hefur tekið pátt í nokkrum samstarfsrannsóknaverkefnum.

Margrét Sigríður Björnsdóttir (margreb@hi.is) er aðjúnkt á Menntavísindasviði Háskóla Íslands og verkefnisstjóri hjá RannUng. Hún lauk grunnskólakennaraprófi frá KHÍ 1989 og M.Ed.-prófi frá Háskólanum í Reykjavík 2009 í stærðfræði og kennslufræði stærðfræðinnar. Margrét hefur starfað bæði í leik- og grunnskóla.

Sara M. Ólafsdóttir (saraola@hi.is) er lektor við Menntavísindasvið Háskóla Íslands. Sara lauk doktorsnámi í febrúar 2019 en rannsókn hennar fjallaði um leik út frá sjónarmiði barna. Samhliða doktorsnáminu hefur hún tekið pátt bæði í innlendu og erlendu rannsóknasamstarfi, meðal annars um vellíðan barna, leik og nám barna og samfellu í skólastarfi. Sara hefur skrifað töluvert af greinum og bókarköflum um efnið.

\section{About the authors}

Dr. Kristín Karlsdóttir (krika@hi.is) is an associate professor in early education at the Faculty of Education, University of Iceland. Her teaching and research touches upon preschool teachers' reflections and professional development, children's participation in play and learning, and children's agency and democracy in preschools. Furthermore, she works with Learning Stories, documentation and assessment in preschool education. Currently she is the head of the research center in early education and has taken part in several collaborative action research projects.

Margrét Sigríður Björnsdóttir (margreb@hi.is) works as an adjunct at the School of Education, University of Iceland and is a project manager at RannUng. She completed her B.Ed. in primary school teaching in 1989 and an M.Ed. in math and pedagogy of math from the University of Reykjavík in 2009. She has worked both as a preschool teacher and as a teacher in primary school.

Dr. Sara M. Ólafsdóttir (saraola@hi.is) is a lecturer at the University of Iceland, School of Education. Her research focus has mainly been on with children in Icelandic preschools. Sara has written articles and book chapters about children's perspectives on play, the transition from preschool to primary school and children's well-being. She has been involved in national and international research projects connected to children's play and learning, transitions from preschool to primary school, and wellbeing.

\section{Heimildir}

Alvestad, T. og Sheridan, S. (2015). Preschool teachers' perspectives on planning and documentation in preschool. Early Child Development and Care, 185(3), 377-392. doi:10.1080/03004430.2014.929861

Anna Kristín Sigurðardóttir. (2013). Skóli sem lærdómssamfélag. Í Rúnar Sigpórsson, Rósa Eggertsdóttir og Guðmundur Heiðar Frímannsson (ritstjórar), Fagmennska í skólastarfi: Skrifað til heiðurs Trausta Dorsteinssyni (bls. 35-53). Reykjavík: Háskólaútgáfan. 
Brooker, L. (2008). Supporting transitions in the early years. Maidenhead: McGraw-Hill.

Bryndís Garðarsdóttir og Kristín Karlsdóttir. (2012). Skráning námssagna. Sjónarhorn barna. Í Jóhanna Einarsdóttir og Bryndís Garðarsdóttir (ritstjórar), Raddir barna (bls. 99-119). Reykjavík: RannUng og Háskólaútgáfan.

Carr, M. (2001). Assessment in early childhood settings: Learning stories. London: Paul Chapman.

Carr, M. (2011). Young children reflecting on their learning: Teachers' conversation strategies. Early Years, 31(3), 257-270. doi:10.1080/09575146.2011.613805

Carr, M. (2014). Play and playfulness: Issues of assessment. Í L. Brooker, M. Blaise og S. Edwards (ritstjórar), The Sage handbook of play and learning in early childhood (bls. 264-276). London: Sage.

Carr, M. og Lee, W. (2012). Learning stories. Constructing learner identities in early education. Los Angeles: Sage.

Carr, M. og Lee, W. (2019). Learning stories in practice. Los Angeles; Sage.

Dahlberg, G., Moss, P. og Pence, A. (2007). Beyond quality in early childhood education and care: Languages of evaluation (2. útgáfa). London: Routledge.

Daniels, K. (2011). Supporting the development of positive dispositions and learner identities: An action research study into the impact and potential of developing photographic learning stories in the early years. Education, 41(3), 300-315. doi:10.1080/03004279.2011.582846

Davis, K., Wright, J., Carr, M. og Peters, S. (2013). Key competencies, assessment and learning stories: Talking with teachers and students. Wellington: NSCER Press.

Giudici, C., Rinaldi, C. og Krechevsky, M. (2001). Making learning visible: Children as individual and group learners. Cambridge, MA: Project Zero og Reggio Children.

Hord, S. og Tobia, E. F. (2012). Reclaiming our teaching profession: The power of educators' learning in community. New York: Teacher College Press.

Jóhanna Einarsdóttir. (2010). Leikskólastarf af sjónarhóli foreldra. Uppeldi og menntun, 19(1-2), 9-31. Sótt af https://timarit.is/view_page_init.jsp?pageId=5283263

Jóhanna Einarsdóttir. (2013). Leikskóli og grunnskóli á sömu leið. Í Bryndís Garðarsdóttir og Jóhanna Einarsdóttir (ritstjórar), Á sömu leið: Tengsl milli leikskóla og grunnskóla (bls. 11-35). Reykjavík: RannUng og Háskólaútgáfan.

Jóhanna Einarsdóttir. (2019). Much changes, much remains the same: Icelandic parents' perspectives on preschool education. Journal of Early Childhood Research, 17(3),220-232.https://doi.org/10.1177\%2F1476718X19849293

Kampmann, J. (2004). Societalization of childhood: New opportunities? New demands? Í H. Brembeck, B. Johansson og J. Kampmann (ritstjórar), Beyond the competent child: Exploring contemporary childhoods in the Nordic welfare societies (bls. 127-152). Frederiksberg: Roskilde Universitetsforlag.

Koshy,V. (2010). Action research for improving practice: A practical guide. London: Sage.

Kristín Karlsdóttir og Anna Magnea Hreinsdóttir. (2015). Námssögur:Tæki til að meta áhuga, virkni og líðan barna í leikskóla. Netla - Veftímarit um uppeldi og menntun. Sótt af https://netla.hi.is/greinar/2015/ryn/008.pdf

Kristín Karlsdóttir og Anna Magnea Hreinsdóttir. (2016). Leikum, larum, lifum. Reykjavík: RannUng og Háskólaútgáfan.

Kristín Karlsdóttir og Bryndís Garðarsdóttir. (2008). Námssögur. Styrkleikar og færni leikskólabarna. Í Jóhanna Einarsdóttir og Bryndís Garðarsdóttir (ritstjórar), Sjónarmið barna og lýdreæði i leikskólastarfi (bls. 133-153). Reykjavík: RannUng og Háskólaútgáfan.

Kristín Karlsdóttir og Bryndís Garðarsdóttir. (2010). Exploring children's learning stories as an assessment method for research and practice. Early Years, 30(3), 255-266. doi:10.1080/09575146.2010.506431

Löfgren, H. (2016). A noisy silence about care: Swedish preschool teachers' talk about documentation. Early Years, 36(1), 4-16. doi:10.1080/09575146.2015.1062744

Mac Naughton, G. og Hughes, P. (2009). Doing action research in early childhood studies: A step by step guide. Maidenhead: Open University Press.

Mayall, B. (2003). Sociologies of childhood and educational thinking. London: Institute of Education.

McNiff, J. (2010). Supporting teachers personally and professionally in challenging environments. (1), 1-15. Sótt af https://dergipark.org.tr/en/pub/tojqi/issue/21388/229332 
McNiff, J. (2013). Action research: Principles and practice. (3rd ed.). London: Routledge, Taylor \& Francis Group.

Mennta- og menningarmálaráđuneytið. (2012). Aðalnámskrá leikskóla 2011. Reykjavík: Höfundur.

Mennta- og menningarmálaráđuneytið. (2013). Demahefti um námsmat í leikskólum. Sótt af https://vinnuvefur. namskra.is/wp-content/uploads/2010/10/N\%C3\%A1msmatshefti-fyrir-leiksk\%C3\%B3la.pdf

New Zealand Ministry of Education. (1996). Te Whāriki. He Whāriki mātauranga mō ngā mokopuna o Aotearoa: Early childhood curriculum. Wellington, NZ: Ministry of Education.

New Zealand Ministry of Education. (2017). Te Whāriki. He Whāriki mātauranga mō ngā mokopuna o Aotearoa: Early childhood curriculum. Sótt af www.education.govt.nz/assets/Documents/Early-Childhood/Te-Whariki-Early-Childhood-Curriculum-ENG-Web.pdf

Oliveira-Formosinho, J. og de Sousa, J. (2019). Developing pedagogic documentation: Children and educators learning the narrative mode. Í J. Formosinho og J. Peeters (ritstjórar), Understanding pedagogic documentation in early childhood education. Revealing and reflecting on high quality learning and teaching (bls. 32-51). London: Routledge.

Peters, S. (2009). Responsive, reciprocal relationships:The heart of the Te Whāriki curriculum. Í T. Papatheodorou og J. Moyles (ritstjórar), Learning together in the early years: Exploring relational pedagogy (bls. 23-32). London: Routledge.

Prout,A. (2011). Taking a step away from modernity: Reconsidering the new sociology of childhood. Global Studies of Childhood, 1(1), 4-14. doi:10.2304/gsch.2011.1.1.4

Prout, A. og James, A. (2015). A new paradigm for the sociology of childhood? Provenance, promise and problems. Í A. James og A. Prout (ritstjórar), Constructing and reconstructing childhood: Contemporary issues in the sociological study of childhood (bls. 6-18). London: Routledge.

Qvortrup, J. (2009). Childhood as a structural form. Í J. Qvortrup, W. A. Corsaro og M.-S. Honig (ritstjórar), The Palgrave handbook of childhood studies (bls. 21-33). Basingstoke: Palgrave Macmillan.

Rinaldi, C. (2005). Documentation and assessment:What is the relationship? Í A. Clark,A.T. Kjörholt og P. Moss (ritstjórar), Beyond listening: Children's perspectives on early childhood services (bls. 29-49). Bristol: Policy Press.

Sara Margrét Ólafsdóttir og Bryndís Garðarsdóttir. (2016).Vellíðan barna í leikskóla - samstarfsrannsókn. Í Kristín Karlsdóttir og Anna Magnea Hreinsdóttir (ritstjórar), Leikum, larum, lifum. Námssvið leikskóla og grunnpettir menntunar (bls. 31-54). Reykjavík: RannUng og Háskólaútgáfan.

Skóla- og frístundasvið Reykjavíkurborgar. (2017). Skýrsla starfshóps: Upplýsingatcekni í leikskólastarfi. Sótt af https://reykjavik.is/sites/default/files/ymis_skjol/skjol_utgefid_efni/130_5.1_ut_leikskolar_nov2017.pdf

Svava Björg Mörk og Rúnar Sigpórsson. (2011). Samfélag jafningja: Uppbygging lærdómssamfélags í leikskóla. Tímarit um menntarannsóknir, 8(1), 38-59. Sótt af https://ojs.hi.is/tum/article/view/2071/1060

Kristín Karlsdóttir, Margrét S. Björnsdóttir og Sara Margrét Ólafsdóttir. (2020). Mat á námi og vellíðan barna. Lærdómur af samstarfsrannsókn í fimm leikskólum. Netla - Veftímarit um uppeldi og menntun. Menntavísindasvið Háskóla Íslands. Sótt af http://netla.hi.is/serrit/2020/mat_nam_vellidan_barna_leikskoli/01.pdf DOI: hhttps://doi.org/10.24270/serritnetla.2020.1 